\title{
Keluarga dan Pendidikan Karakter: Menggali Implikasi Nilai-nilai Hausetafel dalam Efesus 6:1-9
}

Febby Nancy Patty ${ }^{1}$, Vincent Kalvin Wenno ${ }^{2}$, Fiona Anggraini Toisuta ${ }^{3}$

1, 2,3Fakultas Ilmu Sosial Keagamaan, Institut Agama Kristen Negeri Ambon, Maluku

1fenansia@gmail.com@gmail.com, 2vincentkalvin@gmail.com

\begin{tabular}{|c|c|}
\hline $\begin{array}{l}\text { Article History } \\
\text { Submitted: } \\
\text { 28 Pebruary } 2020 \\
\text { Revised: } \\
\text { 06 September } 2020 \\
\text { Accepted: } \\
\text { 14 September } 2020\end{array}$ & $\begin{array}{l}\text { Abstract: The moral crisis in Christian families due to globalization has resulted } \\
\text { in the loss of the function of the Christian family in society. This results in the } \\
\text { shift in family values to be replaced by individualist, consumerist, and hedonistic } \\
\text { values. This article describes the concept of family (hausetafel) in the letters of } \\
\text { Ephesians and Colossians. The author uses a historical socio interpretation, to } \\
\text { search for and find the meaning of the two epistles. The results of the inter- } \\
\text { pretation show that the two epistles are very rich related to family and moral }\end{array}$ \\
\hline $\begin{array}{l}\text { Keywords: } \\
\text { character } \\
\text { education; } \\
\text { Christian family; } \\
\text { Ephesians; }\end{array}$ & $\begin{array}{l}\text { and cultural context. Some of the values contained include the revelation of } \\
\text { the family as a basis for character education, equality relations. The family } \\
\text { image becomes a model for church life. }\end{array}$ \\
\hline $\begin{array}{l}\text { haustafel; } \\
\text { socio-historic } \\
\text { interpretation; } \\
\text { Efesus; } \\
\text { keluarga; } \\
\text { penafsiran } \\
\text { sosio-historis; } \\
\text { pendidikan } \\
\text { karakter }\end{array}$ & $\begin{array}{l}\text { Abstrak: Krisis moral yang terjadi di tengah keluarga Kristen akibat globalisasi, } \\
\text { mengakibatkan hilangnya fungsi keluarga Kristen di tengah masyarakat. Hal } \\
\text { tersebut mengakibatkan bergesernya nilai-nilai keluarga digantikan dengan nilai- } \\
\text { nilai individualis, konsumerisme, hedonistik. Artikel ini memuat tentang konsep } \\
\text { keluarga (hausetafel) dalam surat Efesus } 6: 1-9 \text {. Penulis menggunakan penafsiran } \\
\text { sosio historis, untuk mencari dan menemukan makna atau nilai kekeluargaan } \\
\text { menurut pemikiran Paulus. Hasil penafsiran menunjukkan bahwa penguatan } \\
\text { nilai-nilai keluarga tidak lepas dari konteks sosio-historis dan kulturalnya yang } \\
\text { yang didominasi oleh pola-pola relasi kekuasaan yakni patron-klien yang ber- } \\
\text { dampak pada kehidupan persekutuan umat. Sehingga perlu adanya penguatan } \\
\text { moral dan karakter yang berdasar pada nilai-nilai kekeluargaan. Beberapa nilai } \\
\text { haustafel yang menonjol dalam perikop ini yakni nilai kebenaran, kasih dan }\end{array}$ \\
\hline $\begin{array}{l}\text { DOl: https://doi.org/ } \\
\text { 10.30995/kur.v6i2.155 }\end{array}$ & $\begin{array}{l}\text { ketaatan, penghormatan, nilai persaudaraan, bersikap adil dan hidup setara yang } \\
\text { selanjutnya menjadi model bagi kehidupan gereja maupun kekristenan. }\end{array}$ \\
\hline
\end{tabular}

\section{Pendahuluan}

Dewasa ini terjadi krisis dalam kehidupan keluarga Kristen. Tantangan globalisasi pada satu sisi membawa dampak positif bagi perkembangan kehidupan manusia, namun di sisi lain, membawa dampak negative bagi kemerosotan nilai-nilai etik dan moral. Nilai-nilai kekeluargaan semakin bergeser dan digantikan dengan nilai-nilai individualitstik, konsume-ristik, hedonistik. Kehidupan keluarga Kristen diwarnai oleh berbagai permasalahan mulai dari praktik perceraian, kekerasan dalam rumah tangga (KDRT), sampai sampai kepada berbagai bentuk pengabaikan dan penelantaran terhadap anak-anak. Anak-anak tidak mendapatkan perhatian maupun didikan yang memungkinkan mereka dapat bertumbuh secara sehat. Sehingga, tidak jarang mereka terjerumus dalam berbagai tindakan destruktif mulai dari konflik/tawuran, keter- 
libatan dalam judi, minuman keras (miras) dan obat-obat terlarang (narkoba), praktik seks bebas dan ketiadaan pegangan hidup. Salah satu penyebab dari perilaku itu adalah lemahnya peran dan fungsi keluarga (orang tua) dalam menanamkan nilai-nilai pengajaran moral dan karakter bagi anggota keluarga. Menarik, bahwa teks Efesus 6:1-9 mengandung nilai-nilai kekeluargaan yang dapat dijadikan sebagai model bagi penguatan karakter umat.

Nilai-nilai kekeluargaan dan pendidikan karakter, memang sangat dominan dalam tulisan Paulus, secara khusus surat Efesus 6. Pada surat Efesus sendiri menggunakan gagasan pada surat-surat Paulus terdahulu yang kemudian dikembangkan, yang mana salah satunya surat Efesus sangat memberikan perhatian dan menekankan pada nilai-nilai kekeluargaan dalam membangun relasi antara anggota keluarga; atau yang dikenal juga dengan istilah haustafel. Kode kerumahtanggaan "haustafel" secara dominan muncul dalam surat Efesus. Beberapa teks yang menekankan aspek tersebut, di antaranya Efesus 4:15 yang menekankan gereja sebagai tubuh dan Kristus sebagai "Kepala". ${ }^{1}$ Dalam Efesus 5:22-33 memberikan penekanan pada keluarga Kristen, secara spesifik relasi dan sikap suami terhadap istri maupun sebaliknya istri terhadap suami. Demikian halnya dengan teks Efesus 6:1-9; teks ini berisi nasihat Paulus terhadap keluarga Kristus untuk hidup dalam kasih. Frasa "di dalam Tuhan" (en Kurio) memiliki kese-jajaran dengan nasihat dalam bagian sebelumnya di mana istri harus tunduk kepada suami se-perti "kepada Tuhan" (to Kurio); bandingkan dengan Efesus 5:22.

Tentunya frasa di dalam Tuhan dan kepada Tuhan ini bukan hanya merupakan permainan kata, tetapi ada maksud yang terkandung di balik penggunaan frasa tersebut. Selain itu, Kristus digambarkan sebagai kepala jemaat; dan jemaat adalah anggota dari tubuh Kristus. Hal tersebut menunjuk kepada dimensi kesatuan. Demikian juga kesatuan tersebut mesti nampak juga dalam relasi antar anggota keluarga; anak terhadap orang tua, orang tua ter-hadap anak; maupun tuan dan hamba atau sebaliknya.

Jika menyimak secara saksama, teks Efesus 6:1-9 memang memiliki kesejajaran dengan teks Kolose 3:18-25. Keduanya memiliki kemiripan namun keduanya memiliki latar belakang yang berbeda. Dalam surat Efesus, penulis ingin memperbaiki pengaruh hidup bebas dari lingkungan aliran gnostik atau agama-agama misteri pada saat itu. Untuk mengatasinya, ia menggunakan sejumlah bahan tradisi, yang menyangkut nasihat etis Paulus. Misalnya, nasihat tentang kehidupan keluarga yang diambil dari kebudayaan Yudaisme-Helenisme melalui Surat Kolose, dan pandangan Kristus sebagai Kepala tampaknya berasal dari lingkungan Helenistik dan Gnostik.

Dengan demikian penekanan terhadap nilai keluarga (hausetafel) dalam kaitan Efesus tentu saja tidak dapat dipisahkan dari latar sosio-kultural yang melatarbelakangi pemikiran penulis. Apa sesungguhnya yang menjadi latar belakang sosial-kultural, kandungan nilai-nilai kekeluargaan apa saja yang ditekankan dalam teks Efesus 6 dan maknanya bagi Kekristenan. Masalah tersebut perlu ditelusuri lebih mendalam. Terkait dengan masalah tersebut, artikel ini bertujuan untuk menggali makna atau nilai kekeluargaan yang mengacu pada teks Efesus 6:1-9 dengan menggunakan metode tafsir sosio-historis. Kode kerumahtanggaan "haustafel" dalam

${ }^{1}$ Samuel Benyamin Bakh, Perjanjian Baru: Sejarah, Pengantar Dan Pokok-Pokok Teologisnya (Bandung: Bina Media Informasi, 2010), 226-27. 
perikop Efesus 6:1-9 akan digali dan dianalisis unuk menemukan kandungan nilai-nilai teologis keluarga dan implikasinya bagi penguatan karakter umat.

\section{Metode Penelitian}

Tulisan ini menggunakan pendekatan atau metode tafsir sosio-historis. Pendekatan tafsir sosiohistoris merupakan metode tafsir yang berupaya untuk menjembatani keterbatasan dalam mengungkapkan makna sebuah teks lewat penafsiran historis kritis. Metode ini dikembangkan oleh beberapa tokoh di antaranya Gottwald dan Bruce Malina. ${ }^{2}$ Metode tafsir sosial berupaya menelusuri aspek-aspek sosial dari kehidupan masyarakatnya baik itu dimensi relasi dan pola relasi kemasyarakatan dalam kekristenan baik secara aspek strukturalnya dan fungsionalnya. Dimensi sosial sangat penting dan tidak bisa diabaikan dalam menelusuri makna sebuah teks Alkitab. Untuk itu, dalam pembahasan akan menguraikan interaksi dan hubungan sosial (sinkronik) antara penyebaran Injil dan konteks sosial yang terjadi dalam Efesus. Untuk memahami teks menggunakan model ini, maka dalam proses penafsiran akan memperhatikan analisis karakter sosial seperti latar belakang sosial historis, struktur kelompok dan stratifikasi sosial dari kebudayaannya. ${ }^{3}$

\section{Pembahasan}

\section{Haustafel Code dalam Surat Efesus}

Dasar peraturan rumah tangga dalam Efesus dikenal luas sebagai sebagai hausetafel. Jika memperhatikan struktur dari aturan-aturan tersebut terdapat sebuah pola yang sama yakni penerima nasihat, isi nasihat, alasan teologis pemberian nasihat tersebut. Isi nasihat juga diawali dengan kelompok yang memiliki relasi terdekat (anak-orang tua; suami istri dan majikan hamba). Setidaknya ada dua cara menurut Cannon ${ }^{4}$ untuk memahami hausetafel dalam Efesus mamupun Kolose. Pertama, teks-teks Perjanjian Baru (PB) berasal dari akhir abad pertama dan perkembangan awal kedua yang berakar dalam perkembangan kelompok keagamaan yang mulai terlihat dalam konteks masyarakat Urban. Transformasi radikal dalam struktur masyarakat oleh umat percaya adalah bagian dari kelompok agama minoritas yang mengenai ketegangan dalam hubungan-hubungan dalam tatanan sosial yang lebih luas benar-benar merupakan suatu hal yang tidak mungkin.

Kedua, jemaat Kristen yang didirikan Paulus memahami bahwa dunia di sekarang adalah jahat. Dan untuk keluar dari dunia yang jahat perlu melakukan praktik asketis, yang menganggap tubuh fisik itu harus dikalahkan. Tetapi tubuh itu telah ditransformasi dalam baptisan dan orang percaya yang sudah ditinggikan. Oleh karena itu mereka dapat berpartisipasi dalam harmoni kosmik yang baru. Signifikansi agama di Kolose menawarkan suatu visi kemenangan manusia menghadapi kejahatan yang dapat mencapai proporsi kosmik. Penulis kitab Efesus

${ }^{2}$ Norman K Gottwald and Richard A Horsley, The Bible and Liberation: Political and Social Hermeneutics (Maryknoll, N.Y.: Orbis, 1993); Bruce J Malina, John J Pilch, and Context Group (1986- ), Social Scientific Models for Interpreting the Bible: Essays by the Context Group in Honor of Bruce J. Malina (Atlanta: Society of Biblical Literature, 2007).

${ }^{3}$ Yusak Tridarmanto, Hermeneutika Perjanjian Baru 1 (Yogyakarta: Kanisius, 2013), 37.

${ }^{4}$ George Cannon, The Use of Traditional Materials in Colossians (USA: Mercer University Press, 1983), $10-11$. 
memanggil orang percaya untuk menjalani kehidupan yang saleh, baik, tetapi juga menjaga eksistensi kerumahtanggaan yang menekankan berbagai kode atau aturan yang konvensional. ${ }^{5}$

Lebih lanjut, menurut Cannon ${ }^{6}$, tradisi hausetafel mengandung beberapa karakteristik mendasar. Pertama, nasihat ini ditujukan kepada istri, suami, anak, budak, hamba dan tuan yang muncul dalam konteks sosial dan gereja umat. Kedua, perintah terhadap istri dan budak paling banyak muncul dalam peraturan/hukum kerumahtanggaan (Kolose, Efesus, 1Timotius, 1Petrus) yang menunjukkan bahwa kelas sosial baik istri dan hamba /budak yang paling banyak mendapat perhatian dari struktur masyarakat. Ketiga, skema nasihat dikembangkan dan diaplikasikan dalam situasi kehidupan jemaat yang variatif. Keempat, pihak yang dinasihati harus tunduk/taat kepada yang lainnya. Karakteristik ini menonjol dalam teks Efesus 6:1-9.

\section{Pola Relasi yang Dibangun: Kekuasaan atau Patron-Klien}

Penulis Efesus sangat menekankan kesatuan jemaat yang dianalogikan dalam kesatuan tubuh. Aspek kesatuan dimaksud berwujud baik dalam menjalankan fungsi maupun membangun relasi satu dengan yang lainnya. Salah satu tantangan mendasar yang dihadapi di Efesus yang turut berpengaruh terhadap relasi antar masyarakat maupun umat yakni pola relasi kekuasaan yang dibangun berdasarkan sistim patronage. ${ }^{7}$ Dalam budaya Yunani-Romawi, sistem patronage melibatkan pihak patron (pelindung) dan (klien/orang yang dilindungi). Tujuan utama sistem patronage yakni melakukan pertukaran barang dan jasa, terutama kekuasaan, pelindungan dan pengaruh di antara orang-orang yang berbeda status sosialnya dan tidak memiliki relasi kekeluargaan (kinship). Sistem patronage dijalankan menurut beberapa prinsip umum yang bersifat resiprokal, personal, asimestris, sukarela, legal, sambil menanamkan nilai -nilai kepercayaan (trust) melakukan pertukaran barang dan jasa, terutama perlindungan, kekuasaan. ${ }^{8}$ Relasi-relasi di atas juga berpengaruh dalam kehidupan anggota masyarakat dan lebih spesifik terhadap jemaat Kristen.

Lenski melalui studinya terhadap tipe masyarakat agraria mengatakan salah satu fakta yang menandai kehidupan masyarakat agraria yakni social inequality. Menurutnya dalam laju pertumbuhan ekonomi agraria masyarakat dibagi atas stratifikasi sosial berdasarkan power (kekuasaan), privilege (hak-hak istimewa) dan honour (kehormatan). ${ }^{9}$ Di antara ketiga hal tersebut kekuasaan merupakan kunci penting. Model Lenski membagi masyarakat agraria kekaisaran Romawi atas 7 bagian mulai dari kelas atas (upper class) masyarakat kelas atas adalah kalangan elite dan orang-orang kaya dan kelas masyarakat kelas bawah (lower class). Dari stratifikasi di atas, yang termasuk kelas bawah di antaranya para petani, para tukang, kaum buruh, para pekerja dan para budak, pengemis, pengangguran, termasuk di antaranya kaum perempuan. Stratifikasi sosial mana berpengaruh terhadap relasi dan pola-pola relasi yang dibangun antara kelompok dan komunitas; yang kaya semakin bertambah kaya dan yang miskin semakin

\footnotetext{
${ }^{5}$ Margareth Macdonald, Colossians Ephesians (Sacra Pagina: Liturgical Press, 2008), 14-15.

${ }^{6}$ Cannon, The Use of Traditional Materials in Colossians, 109-11.

${ }^{7}$ Monike Hukubun, "Nuhu-Met Sebagai Tubuh Kristus Kosmik: Perjumpaan Makna Kolose Dengan Budaya Sasi Melalui Hermeneutik Kosmik” (Universitas Kristen Duta Wacana, 2018), 42.

${ }^{8}$ Hukubun, 82-85.

${ }^{9}$ Gerhard Lenski, Power and Privilege: A Theory of Social Stratification (London: University of North California Press, 1984), 210.
} 
menderita dan terpinggirkan. Hal ini bukan saja tampak dalam kehidupan masyarakat namun juga kehidupan keluarga.

Perempuan dalam kehidupan abad pertama sering kali mengalami nasib yang buruk karena tidak memiliki kedudukan atau status sama dengan laki-laki. Kaum perempuan sama dengan budak yang dianggap sebagai barang. Karna itu rentang sekali didominasi, menerima perlakukan kekerasan, dan diperlakukan secara tidak adil. Hal itu bukan saja terjadi dalam relasi individu tapi keluarga. Sering kali perempuan diperlakukan dengan tidak adil dan mendapat perlakukan kekerasan. Demikian juga dengan hamba.

Secara khusus Barclay mengatakan, kehidupan seorang hamba sangat berat dan mengerikan. Secara hukum seorang hamba dianggap bukan manusia tapi benda. Hamba disamakan dengan barang, benda, perkakas, bahkan hamba juga dianggap sebagai binatang yang kebetulan dapat berbicara. Yang sudah tua dan tidak berguna disingkirkan dan ditimbun saja sebagai barang bekas sampai ia mati kelaparan. Jika seorang hamba sakit maka ia tidak akan menerima upah. Jika menerima upah, dianggap sebagai sebuah pemborosan. Seorang tuan memiliki kuasa atas hidup dan mati hambanya. Jika hamba berlaku salah, bisa saja ia dihukum mati atau dibunuh oleh tuan atau majikannya.

Ada seorang penulis Romawi bertutur demikian: apa pun yang dilakukan oleh tuan atas hambanya, entah itu dengan pertimbangan atau tidak, baik dalam keadaan marah ataupun atas dasar kemauan baik, secara sadar maupun tidak, semuanya itu adalah keputusan, keadilan dan hukum. ${ }^{10}$ Sedangkan Joel Green mengatakan, dalam dunia Romawi, seorang budak berada di bawah kontrol majikannya (tuannya). Ia tidak bebas untuk melakukan sesuatu terhadap dirinya, sebab tubuh dan segala hal yang dimilikinya berada di bawah kontrol majikannya. Bila seorang budak telah mengakhiri masa kerjanya, ia dapat tidak dipeduli sampai mati. Ia bahkan tidak berhak untuk menikah dan bila ia hidup bersama dan mempunyai seorang anak, anaknya menjadi miliki tuannya. ${ }^{11}$ Seorang budak mengalami kematian sosial. Artinya ia tidak lagi bisa berelasi dengan dunia sosial atau orang lain karena tubuh dan hidupnya dieksploitasi oleh majikannya. ${ }^{12}$ Dimensi sosial kultural inilah yang melatarbelakangi penulisan surat Efesus terkait dengan relasi hamba dan majikan.

\section{Ungkapan “dalam Tuhan” sebagai Sebuah Imperatif Membangun Relasi antar Sesama}

Penekanan terhadap aspek kesatuan dan kekeluargaan penting sebagai sebuah sikap penolakan atau kritikan terhadap pola-pola relasi patron-klien yang dibangun oleh masyarakat berdasar atas sistem kekuasaan. Pada tataran inilah pola kesatuan dan relasi antar anggota keluarga menjadi penting dalam upaya menciptakan tata aturan yang baru dalam kekristenan, dan sama sekali berbeda dengan pola-pola relasi yang dibangun dalam kehidupan masyarakat Yunani dan termasuk umat Kristen. Sebuah tata aturan yang dibangun atas dasar Kristus sebagai Kepala atas jemaatnya. Bahwa tidak demikian umat Kristen (kekristenan). Kehidupan umat Kristen mesti dibangun berdasarkan Tuhan (Firman Tuhan). Sehingga frasa en kurio mengandung di-

${ }^{10}$ Willian Barclay, Pemahaman Alkitab Sehari-Hari, Surat Galatia Dan Efesus (Jakarta: BPK Gunung Mulia, 2015), 271-73.

${ }^{11}$ Barclay, 245-49

${ }^{12}$ Joel Green, "Slaves and Slavery in the Roman World", The World in the New Testament (Michigan: Grand Rapids, 2013), 169-76. 
mensi teologis yang mendalam dan merupakan sebuah imperatif dalam membangun relasi antar sesama termasuk dalam kehidupan keluarga, yang selanjutnya membedakan identitas umat atau kekristenan dari yang lain. Relasi mana digambarkan dalam relasi antar anggota-anggota keluarga baik anak terhadap orang tua maupun sebaliknya. Demikian juga tuan dan hamba. Kata hupakouete muncul dalam perikop dalam ayat 1 dan ayat ke 5 merupakan Kata kerja bentuk Imperatif yang berarti: dengarkan, taatlah, tunduklah. Seorang anak mesti taat atau patuh kepada orang tua dalam Tuhan. Demikian juga seorang hamba kepada tuannya. Demikian halnya juga dalam relasi antara suami dan istri.

Istilah yang sama muncul juga dalam relasi antara suami-istri dan sebaliknya istri terhadap suami muncul dalam bagian ini. Secara sosial kultural, dalam hukum Romawi, suami dianggap sebagai kepala keluarga dalam rumah tangga. Istri dan budak serta anak-anaknya ada di bawah kekuasaan laki-laki. Suami sebagai pater familia (kepala keluarga). Kekuasaan lakilaki disebut dengan Patria Potestas. Menurut hukum ini, istri adalah milik suaminya. Demikian juga anak-anak. Terkadang suami dapat menjatuhkan hukuman kepada istri jika ia ternyata tidak setia, Istri tidak memiliki apa pun sebagai miliknya sendiri. Bahkan yang dibawanya atau diwariskan keluarganya menjadi milik suaminya. ${ }^{13}$

Dan karena peran dan fungsi tersebut maka relasi antar suami dan istri atau sebaliknya istri dan suami. Dunia wanita hanya terbatas di rumah, dan di rumah ia sama sekali tunduk kepada suaminya. Menjelang abad pertama sesudah Masehi, ada upaya untuk melindungi hakhak perempuan. Akan tetapi suami masih memiliki kuasa dalam memutuskan segala masalah keluarga. Suami juga memutuskan nasib anak-anak, budak-budak yang dibeli, tempat tinggal, usaha yang dijalankan keluarga. Zinah oleh istri adalah kejahatan melawan suaminya sedangkan oleh laki-laki hanya pelanggaran terhadap milik orang lain, yakni istri orang itu.

Bagi orang Yunani, dunia wanita hanya terbatas di rumah. ${ }^{14}$ Ia tunduk kepada suaminya. Bagi dunia Romawi manusia wanita dipandang rendah, dipandang makhluk yang kurang akal sehatnya dan tidak mampu berpikir secara logis. Wanita tergolong orang yang kurang berarti, budak-budak, orang bisu dan tuli, artinya orang yang akal budinya tidak dapat dipercaya. ${ }^{15} \mathrm{Hal}$ tersebut terjadi dengan anak-anak. Dalam kebudayaan Romawi, terdapat banyak hal yang bisa membahayakan anak-anak, ayah bisa saja menjual mereka sebagai budak, mempekerjakan di ladangnya bahkan menghukum mereka dengan keras (melakukan kekerasan) terhadap anakanaknya yang bisa membawa kepada maut. Sehingga frasa dalam Tuhan, hendak mempertegas identitas kekristenan (gereja) sebagai yang telah dipersatukan sebagai anggota dari satu tubuh Kristus. Yang dimaksudkan yakni kesatuan gereja sebagai Tubuh Kritus, yang adalah Kepala bagi gereja (umat), yang berbeda dengan yang lain.

\section{Kandungan Nilai-nilai Hausetafel dalam Relasi antar Keluarga}

Dari penjelasan di atas, maka penulis memberikan penguatan pada nilai-nilai teologi kekeluargaan, di mana dasar utama dari bangunan hidup keluarga adalah iman secara vertikal yakni dalam Kristus. Hal tersebut kemudian berlanjut dalam relasi horisontal antar anggota-anggota

\footnotetext{
${ }^{13}$ John Wijngaards, Yesus Sang Pembaharu (Yogyakarta: Kanisius, 1994), 137.

${ }^{14}$ Carolyn Osiek and David L. Balch, Families in the New Testament World (Louisville: Westminster John Knox Press, 1997), 44.

${ }^{15}$ Osiek and Balch, 138.
} 
keluarga. Pertama, nilai "kebenaran". Nilai kebenaran ini merupakan dasar bagi sikap taat kepada Tuhan maupun orang tua. Dalam ayat 1 dikatakan: "Hai anak-anak, taatlah orangtuamu dalam Tuhan karena haruslah demikian" (terjemahan LAI). Kalimat touto gar estin dikaion diterjemahkan secara harfiah: "karena itu adalah benar." Kata "benar" (Yunani: dikaion) yang bisa diartikan juga dengan righteous (kebenaran/keadilan); honest (kejujuran): innocent (tak bercela). Barclay Neumann dalam menjelaskan istilah tersebut berhubungan dengan sebuah standar, nilai, norma atau menunjuk kepada karakter Allah. ${ }^{16}$ Oleh karena karakter Allah adalah kebenaran, dan Allah menghendaki standar itu juga yang harus menjadi dasar dari hubungan atau relasi manusia dengan-Nya, dan juga berlanjut pada relasi manusia dengan sesamanya (band. Mat. 6:1; 20:4; Luk. 12:57; Kol 4:1).

Kedua, nilai penghormatan. Anak-anak harus menaruh rasa hormat kepada orang tua, yakni ayah dan ibu (ayat 2). Penghormatan kepada orang tua bukan saja merupakan suatu perintah namun di balik itu ada suatu janji: "supaya kamu berbahagia dan panjang umur di bumi" (terjemahan LAI). Ada dua aspek penting dari janji ini. Pertama, frasa ina eu soi genesai (LAI: supaya kamu berbahagia). Secara harfiah frasa tersebut daapat diterjemahkan: supaya kamu menjadi baik (Yunani: eu soi), sementara RSV dan KJV menerjemahkan istilah tersebut dengan well, yang artinya baik. Kata "baik" adalah bentuk adverb yang menerangkan keadaan si pelaku (anak-anak) akibat ketaatan/kepatuhan terhadap nasihat orang tua. Kata tersebut lebih luas dari sekadar berbahagia, yakni menjadi baik, untung, besar, makmur/sejahtera. Aspek kedua adalah frasa makrochronios epi tes ges (LAI: panjang umur di atas bumi). Kata tersebut hanya digunakan dalam ayat ini (Ef. 6:3) dan tidak dijumpai dalam teks lainnya dalam Perjanjian Baru. Pertanyaannya, apakah yang dimaksud oleh penulis adalah umur panjang yang menunjuk kepada usia seseorang; bahwa secara fisik anak-anak yang patuh atau taat kepada orang tua akan hidup lama/panjang, atau adakah sesuatu yang terungkap dibalik penggunaan kata tersebut? Jika mengamati istilah yang digunakan sebelumnya, maka kata eu biasanya dikaitkan dengan value dan moral. Louw-Nida mengatakan, bahwa istilah tersebut lebih luas menunjuk kepada kualitas etika dan moral, berkaitan dengan perilaku seperti: kebaikan, kejujuran, kebenaran, kekudusan. ${ }^{17}$ Ini berarti bahwa aspek lama atau panjang yang ditekankan di sini bukan semata-mata menunjuk kepada usia atau umur seseorang, melainkan pada aspek kualitas nilai atau moral dimiliki oleh anak-anak, yang tidak dapat dibatasi oleh ruang dan waktu (lasting), yang memiliki sisi kegunaan bukan saja untuk masa sekarang tetapi juga akan datang.

Ketiga, nilai-nilai edukasi. Hal ini muncul dalam ayat 4, “...dan kamu bapa-bapa, janganlah bangkitkan amarah di dalam hati anak-anakmu, tetapi didiklah mereka di dalam ajaran dan nasihat Tuhan" (LAI). Jika bagian awal nasihat disampaikan kepada anak-anak terhadap orang tua, justru dalam bagian ini terbalik, orang tua terhadap anak-anak. Istilah me parorgizete ta tekna secara harfiah diterjemahkan make angry (membangkitkan amarah atau menekan), merupakan bentuk imperatif sekaligus sebuah larangan yang ditujukan kepada para bapak (Ef.6:4). Gambaran anak dan orang tua (ayah) dalam teks Efesus seakan-akan menegaskan tanggung jawab terhadap anak itu hanya berpusat pada laki-laki (bapa-bapa) dan bukan

\footnotetext{
${ }^{16}$ Barclay M. Newman, Kamus Yunani-Indonesia (BPK Gunung Mulia, 1996).

${ }^{17}$ Johannes P Louw and Eugene Albert Nida, Greek-English Lexicon of the New Testament Based on Semantic Domains. Vol. 2 Indices (United Bible Soc., 1989).
} 
ibu-ibu. Menurut Green, bapak memiliki status sosial yang tinggi dan memiliki status hukum dalam keluarga serta memiliki kekuasaan mutlak atas anak-anak dan seluruh properti yang dalam rumah. ${ }^{18}$ Para ahli menggunakan istilah latin: pater familias untuk menjelaskan semua kuasa mutlak yang dimiliki oleh sang bapak. Dalam rumah, kekuasaan, ruang publik dan privat dibagi sesuai dengan status lebih dari gender. Sedangkan ibu di rumah berhak atas budak dalam rumah, mengatur dapur dan berada di bawah kekuasaan laki-laki. Sedangkan anak-anak tidak memiliki hak privat, kurang menerima kasih sayang dalam keluarga, mereka tidak terlalu penting bagi orang tua tapi bagi keluarga besar. ${ }^{19}$ Lebih lanjut Green mencatat ada empat aspek yang penting terkait dengan kehidupan anak-anak pada masa Romawi yakni: Nilai anak akan tinggi jika mereka bisa berkontribusi dalam dunia sosial; kurang menerima pemberian kasih sayang dari orang tua; mayoritas anak bertumbuh dalam kemiskinan dan tingkat kehidupan yang rendah; anak tidak terjamin kehidupannya dan tidak merasa aman dalam keluarga. ${ }^{20}$

Sedangkan menurut Barclay, dalam dunia kuno, anak-anak sangat dikuasai oleh orang tua mereka. Salah satunya tampak adalah hukum Romawi Patria Potestas, hukum tentang kuasa sang ayah. Menurut hukum itu, seorang ayah boleh berbuat apa saja yang ia ingini terhadap anaknya. Ia boleh menjual anaknya sebagai budak, ia dapat menyuruhnya bekerja sebagai buruh di ladangnya, ia bahkan berhak menghukum anaknya sampai mati dan melaksanakan hukum itu. Semua hak anak dipegang oleh orang tua dan segala kewajiban dipegang oleh anak. ${ }^{21}$ Relasi orang tua dan anak bukan didasarkan atas relasi kasih tapi sebaiknya dominasi kekuasaan. Anak dipandang sebagai yang lemah atau objek sehingga bebas diperlakukan dan didominasi menurut kehendak dan kepentingan dari kekuasaan sang bapak.

Aturan ini memberikan penguatan terhadap tanggung jawab keluarga, yakni orang tua (bapak) terhadap kehidupan anak-anaknya. Istilah dalam Tuhan menunjuk kepada dimensi teologis atau dasar teologis dari aturan yang disampaikan. Secara sosial keharmonisan sebuah keluarga akan berwujud ketika keluarga tersebut menjalankan peran dan fungsi-fungsinya secara optimal. Keluarga dituntut berperan dan berfungsi untuk mencapai kehidupan masyarakat yang bahagia dan sejahtera. Fungsi tersebut dimainkan oleh lembaga yang terkecil, yakni keluarga, khususnya orang tua terhadap anak-anaknya. Nilai edukasi tersebut adalah paidea dan nouthesia. Menarik jika mengamati beberapa terjemahan lainnya, bagian ini diterjemahkan secara berbeda-beda. Terjemahan NIV: Bring them up in the training and instruction of the Lord. Terjemahan KJV: Bring them up in the nurture and admonition of the Lord. BIS menerjemahkan: Didiklah mereka dengan tata tertib dan pengajaran Tuhan. Sedangkan terjemahan LAI: didiklah mereka dalam ajaran dan ajaran Tuhan.

Istilah paidea secara harfiah berarti discipline (disiplin); instruction (ajaran/instruksi), training (latihan). Friberg, dalam Analytical Greek Lexicon, mengartikan kata tersebut dengan: "mengarahkan/menuntun anak-anak kepada kedewasaan", "instruksi”, "latihan”, "disiplin". Itu berarti tugas mendidik atau mengajar terkait erat dengan aspek disiplin sebagai sebuah latihan

\footnotetext{
${ }^{18}$ Joel Green, "Woman, Children and Families in the Grece-Roman World," in The World in the New Testament (Michigan: Grand Rapids, 2013).

${ }^{19}$ Sandra Marie Schneiders, Women and the Word: The Gender of God in the New Testament and the Spirituality of Women, vol. 1986 (Paulist Press, 1986).

${ }^{20}$ Green, "Woman, Children and Families in the Grece-Roman World," 179-85.

${ }^{21}$ Barclay, Pemahaman Alkitab Sehari-Hari, Surat Galatia Dan Efesus, 244.
} 
bagi anak-anak sehingga mereka tetap berpegang kepada ajaran Tuhan. Sedangkan Thayer, dalam Greek- English Lexicon of the New Testament, mengatakan istilah tersebut meliputi: semua latihan dan pendidikan terhadap anak (berhubungan dengan perkembangan pikiran, jiwa dan moral). Instruksi yang mana bertujuan untuk menambahkan kebajikan (2Tim. 3:16). Instruksi, latihan, disiplin akan membentuk perilaku dan moral anak menjadi baik. Green mengatakan, anak-anak sejak umur 7 tahun sudah diajarkan untuk menjadi kuat dalam disiplin dan mengontrol diri mereka. Hal tersebut terkait dengan pelajaran akademik secara formal dan juga moral dalam karakter. Orang tua bertanggung jawab untuk proses sosialisasi anak. ${ }^{22}$

Di lain sisi kata dasar yang berikut yakni: nouthesia menunjuk pada kegiatan teaching (pengajaran), instruction (teguran, peringatan), admonition (peringatan, teguran, nasihat). Menurut Friberg, istilah ini menunjuk kepada pengajaran etis yang berhubungan dengan belief dan behavior. Seorang instruktur bertugas untuk melatih anak-anak yang tidak mengikuti pendidikan formal. David Aune mengatakan bahwa pendidikan anak mulai dari rumah yang dilakukan oleh orang tua atau instruktur yang berbeda secara sosial yang bertanggungjawab terhadap pendidikan awal dari seorang anak.

Di sinilah pentingnya peran dan fungsi keluarga atau orang tua terkait dengan pengajaran nilai-nilai etis atau moral, dan karakter yang berhubungan dengan nilai-nilai keagamaan. Berdasarkan penjelasan di atas, dari segi penggunaan kata, kedua istilah tersebut sebenarnya hampir mirip yakni terkait erat dengan aspek pendidikan atau pengajaran tetapi sesungguhnya memiliki kedalaman makna (teologis) yang berbeda. Kata paidea lebih menunjuk kepada aspek pendidikan, pengajaran, latihan, disiplin, teguran, hukuman (band. 2Tim 3:16; Ibr. 12:5, 7, 8, 11) yang bertujuan untuk mendidik, mengajar, menuntun anak-anak sehingga mereka bertumbuh menjadi lebih dewasa baik segi akal budi maupun perilaku.

Sedangkan kata nouthesia, yakni pengajaran/nasihat berhubungan dengan nilai-nilai etika, moral dan keagamaan, yang bersumber dari ajaran Tuhan (Kis. 20:31; Rm. 15:14; Tit. 3:10; 2Tes 3:15). Hal ini tentu saja berbeda dari sikap orang tua terhadap anak dalam dunia Romawi. Oleh sebab itu, kalimat tersebut tidak berhenti di situ, tetapi diakhiri dengan nasihat Tuhan. Sekalipun demikian, baik tanggung jawab pengajaran maupun nasihat tersebut sama-sama bertujuan untuk mendewasakan anak-anak. Tanggung jawab orang tua diandaikan dengan memberikan makan/gizi (to nourish, to rear), bukan pada aspek fisik/jasmaniah tetapi soal kualitas pikirannya (kognitif), maupun kualitas etik dan moral, sehingga anak-anak memiliki kepribadian dan moralitas yang baik.

Dengan kata lain, lewat nasihat di atas, penulis surat Efesus hendak menekankan posisi sentral Tuhan atau Kristus dalam kehidupan orang percaya (keluarga Kristen); bahwa mereka adalah orang-orang yang telah ditebus, sehingga iman atau kepercayaan mereka kepada Tuhan telah menempatkan pada kedudukan baru sebagai ciptaan yang baru (Ef 2:3; 5-6). Hal mana berdampak secara praktis pada iman dan moralitas mereka. Orang-orang Kristen tidak boleh hidup dalam perbuatan kegelapan, sebab itu tidak akan membuahkan apa-apa (Ef 5:11). Sebaliknya mereka mesti hidup dituntun oleh roh (Ef 5:18) sehingga membuahkan hasil yang baik dalam kehidupan mereka sehari-hari. Demikian halnya dalam kehidupan sosial, kasih Kristus

\footnotetext{
22 Barclay, 183-84.
} 
mesti menjadi dasar dari relasi mereka baik dalam relasi dan kewajiban antar anggota keluarga maupun relasi maupun kewajiban dalam pekerjaan. ${ }^{23}$

Kelima, kasih, pelayanan, dan kesetaraan. Hal tersebut nampak dalam bagian selanjutnya yakni, relasi tuan-hamba atau hamba-tuan. Dalam bagian ini kembali seruan hupakuote diulangi sekali lagi. Tetapi kali ini bukan kepada anak-anak lagi tetapi ditujukan kepada kurios (tuan/majikan). Sama seperti kepatuhan/ketaatan anak terhadap orang tua, maka seorang hamba harus taat/patuh kepada tuan (majikan) mereka yang ada di dunia. Kepatuhan seorang hamba harus nampak dalam pelayanan yang dilakukan terhadap majikan/tuannya. Beberapa sikap yang ditunjukkan adalah takut (phobou) dan gentar (tromou). Yang dimaksudkan di sini bukan rasa takut yang negatif terhadap seseorang, tetapi rasa takut atau rasa hormat seseorang kepada orang lain. Kata ini biasanya digunakan dalam tulisan-tulisan Perjanjian Baru menunjuk kepada takut akan Tuhan. Seorang hamba harus taat atau patuh dengan rasa takut dan gentar kepada tuannya, sama seperti kepada Kristus. Ciri ini mesti menjadi bagian dari kehidupan jemaat Efesus, khususnya seseorang yang bekerja atau mengabdi kepada tuannya. Rasa takut dan hormat bukan karena kedudukan atau status yang lebih rendah dari yang lain tetapi karena panggilan ketaatan untuk mengabdi atau bekerja dengan sungguh-sungguh kepada tuannya.

Seorang hamba juga harus melayani dengan tulus hati. Secara harfiah frasa tersebut diterjemahkan ketulusan, kesetiaan atau kemurnian hati. Terjemahan KJV, RSV dan NIV menggunakan kata yang sama yakni singleness of heart. Secara harfiah frasa aploteti tes kardias diartikan single-heart devotion, singleness, sincerity (Bible Work). Perasaan tersebut dalam tulisan Perjanjian Baru selalu dipertentangkan dengan tidak setia, tidak tulus hati, dusta, kebohongan, kelicikan (band. IKor. 1:12; 2Kor. 11:3; Kol. 3:22). Dengan kata lain, ketaatan atau kepatuhan seorang hamba kepada majikannya harus tulus bukan ketaatan yang dibuat-buat atau karena dipaksa atau terpaksa. Ketulusan yang bersumber dari kedalaman perasaan hati dan batin yang dalam; "Jangan hanya di hadapan mereka untuk menyenangkan hati orang." Frasa "Di hadapan mereka" dalam bahasa Yunani me kat ophthalmoudoulon, yang secara harfiah diterjemahkan eyeservice (di depan atau di hadapan mata).

Hanya satu kali kata ini digunakan dalam PB, yakni pada Efesus 6. Mungkin merupakan penggabungan dua kata yakni ophtalmos dan doulian. Menunjuk kepada suatu pekerjaan atau pelayanan yang tidak dilakukan atas dasar kepatuhan yang mendalam atau tidak memiliki dedikasi dan komitmen terhadap pelayanan yang dilakukan. Sebaliknya pelayanan yang dilakukan semata-mata karena berdasar atas kepentingan-kepentingan orang lain yakni menyenangkan orang lain (RSV dan KJV: men-pleasers). Seorang hamba juga harus melakukan pelayanan dengan segenap hati. Istilah "dengan segenap hati" berarti good will doing service, atau kemauan baik melakukan pelayanan (band. RSV dan KJV), sedangkan NIV menerjemahkan frasa tersebut dengan serve wholeheartedly (melayani dengan segenap/sepenuh hati). Sedangkan BIS menggunakan "dengan hati yang gembira”. Dengan kata lain, menunjuk kepada suatu pekerjaan yang dilakukan dengan sepenuh hati, totalitas hidup, dengan penuh sukacita dan tidak karena terbeban atau bersungut-sungut. Pelayanan yang dilakukan seperti layaknya kepada

\footnotetext{
${ }^{23}$ John Drane, Memahami Perjanjian Baru, (Jakarta:BPK Gunung Mulia, 2001), h.387
} 
Tuhan dan bukan manusia. Pernyataan ini hendak menegaskan aspek panggilan dalam pelayanan yang dilakukan.

Selain itu ada juga nilai kesetaraan. Artinya relasi tuan dan hamba atau sebaliknya hamba dan majikan, bukanlah relasi yang saling mendominasi tapi relasi yang setara. Seorang tuan dan hamba dalam melakukan pelayanan mesti berlandaskan kasih dan bukan karena memandang muka atau diskriminasi. Pada akhirnya segala perbuatan baik yang dilakukan baik kepada anak-orang tua, orang tua-anak, hamba-tuan dan tuan-hamba, maupun kepada setiap orang termasuk orang merdeka, tidak sia-sia karena akan mendapatakan balasannya dari Tuhan. Hal ini penting untuk meneguhkan iman umat terhadap nasihat atau ketetapan yang tertuang dalam perikop.

\section{Implikasinya}

Dari penafsiran sosio-historis di atas, maka teks memiliki makna yang mendalam, yang tidak bisa dipisahkan dari situasi sosio-kultural masyarakatnya. Aspek keluarga bukan saja ditonjolkan dalam perikop ini, namun muncul juga secara berulang-ulang dalam bagian teks lainnya. Demikian juga pada gambaran Kristus yang adalah Tuhan atau Kepala segala sesuatu, termasuk rumah tangga atau keluarga (Ef. 1:10). Dalam Kolose disebutkan, Yesus adalah gambar Allah yang sulung, di dalam Dia diciptakan segala sesuatu di sorga maupun di bumi. Ialah terlebih dahulu dari segala sesuatu dan segala sesuatu ada di dalam Dia. Ialah kepala tubuh yakni Jemaat, Ialah yang sulung, yang pertama bangkit dari orang mati, sehingga Ia lebih utama dari segala sesuatu (Kol. 1:15-18). Itu berarti Allah (Yesus) juga menciptakan jemaat atau keluarga. Keluarga terbentuk bukan karena prakarsa manusia, tetapi karena diciptakan dan dibentuk oleh Allah melalui Yesus Kristus. Ia adalah Tuhan dan Kepala atas keluarga. Konsep teologis ini penting sebagai dasar untuk memahami eksistensi keluarga termasuk anggota keluarga, di mana orang Kristen harus memahami bahwa keluarga bukan saja merupakan institusi sosial, tetapi juga berdimensi religius. Dimensi religius keluarga Kristen berbasis pada karya penciptaan dan pengorbanan Yesus yang telah membentuk dan menata keluarga dalam sebuah tatanan yang baik dan harmonis.

Jemaat, secara khusus keluarga, adalah sentra dari maksud dan tindakan keselamatan Allah. Allah menyelamatkan manusia dan dunia melalui, dan di dalam keluarga. Sebab itu kehadiran keluarga merupakan gambaran atau representasi dari kehadiran dan cinta kasih Allah bagi umat-Nya. Allah (Yesus) juga adalah kepenuhan dari segala sesuatu dan segala sesuatu bersumber dalam Dia, termasuk juga dengan kehidupan keluarga. Kristus bukan saja dasar dari segala sesuatu tapi juga seluruh aturan-aturan etika maupun moral yang ada dalam rangka mengatur kehidupan keluarga satu dengan yang lainnya. Penguatan moral serta karakter umat harus dilakukan melalui proses edukasi, nasihat, pengajaran, didikan dan disiplin. Kesadaran inilah yang mesti dibangun dan menggerakkan anggota keluarga (umat) untuk berelasi dan membangun kehidupan yang benar.

\section{Keluarga sebagai Basis Pendidikan Karakter Umat}

Keluarga Kristen mesti menjadi basis utama tempat penyemaian nilai-nilai etika moral. Nilai tersebut nampak dalam kata paidea dan nouthesia yang berfokus kepada penguatan nilai-nilai karakter umat yang dimulai sejak masa kanak-kanak. Sejak kecil anak-anak mesti diajarkan dan dididik dengan cinta kasih yang bersumber dari kasih Tuhan. Pendidikan dan pengajaran 
tersebut bertujuan agar membentuk anak-anak menjadi generasi yang takut akan Tuhan. Proses pembinaan yang dilakukan bukan terjadi satu kali, melainkan berkelanjutan melalui pendidikan formal maupun non formal. Karena itu peran orang tua (pengajar) sangat penting dalam proses mengedukasi maupun sosialisasi nilai-nilai karakter salah satunya yakni nilai-nilai kesatuan, kekeluargaan dan perdamaian (non violence).

Sejak kecil anak-anak harus dilatih dan dibina untuk takut akan Tuhan dan mempraktikkan hidup yang benar (baik), saling mengasihi dan saling menghormati, saling melayani satu dengan yang lain dan bersikap adil terhadap semua orang. Pendidikan/pengajaran tersebut bertujuan untuk kehidupan dan keselamatan hidup mereka. Pengajaran dan pendidikan yang dilakukan terhadap anak-anak mesti dilakukan dalam cinta kasih bukan menggunakan cara-cara kekerasan. Keluarga Kristen mesti menjadi locus dimana melaluinya semua orang dapat hidup dalam nilai-nilai kesatuan dan kekeluargaan, semua orang saling berterima dan merangkul, walaupun berbeda dalam peran dan fungsi. Dewasa ini terjadi kemerosotan nilai-nilai karakter yang salah satunya juga disebabkan karena lemahnya peran dan fungsi orang tua (pemimpin) dalam membina, mendidik, mengarahkan, menegur anak-anak. Orang tua lebih banyak sibuk dengan urusan dan pekerjaannya ketimbang mengurusi mental dan moral anak-anak. Di sinilah pentingnya pengajaran (pendidikan) Kristen dalam membentuk moral dan karakter anak.

\section{Gambaran Keluarga sebagai Model bagi kehidupan Gereja}

Aturan atau hukum keluarga (haustafel) sesungguhnya menjadi sebuah standar dalam membangun kehidupan kekristenan, baik eksternal maupun internal. Nilai atau kode haustafel menjadi gambaran atau model bagi masyarakat atau gereja dalam membangun kehidupan antar sesama yang saling setara dan adil dan berlandaskan kasih. Membangun jemaat atau gereja harus berawal dari kehidupan keluarga. Keluarga Kristen mesti menjadi dasar bagi pembentukkan dan pewarisan nilai-nilai moral, etik dan spiritual yang seluruhnya berdasar pada Firman Tuhan. Firman Tuhan adalah standar sekaligus landasan moral dalam membangun relasi antar anggota keluarga satu dengan yang lainnya.

Dasar kehidupan keluarga Kristen adalah Tuhan, kepala atas keluarga yang menciptakan dan membentuk keluarga. Sehingga setiap umat mesti menyadari tentang esensi dirinya dan panggilannya sebagai anak-anak Allah yang dipanggil untuk menyampaikan karya Kristus bagi dunia dan sesama. Hanya dengan demikian, setiap orang dapat melakukan fungsi dan perannya sesuai dengan aturan-aturan yang harus dilakukan dalam keluarga. Allah menyelamatkan umat-Nya melalui, dan di dalam keluarga. Karena itu, setiap orang yang telah merasakan kasih dan cinta Tuhan harus berupaya untuk hidup bersesuaian dengan kehendak dan Firman Tuhan. Hanya dengan demikian orang akan mengalami kehadiran dan kasih Allah bagi umat-Nya.

Keluarga mesti menjadi rumah bersama yang memberikan rasa nyaman dan aman bagi segenap anggota keluarganya. Setiap anggota keluarga mesti merasa betah dalam keluarga karena ia dikasihi, dicintai, dilindungi dan diperlakukan secara adil. Realitas yang terjadi, lingkungan keluarga dan masyarakat menjadi tidak sehat karena diwarnai dengan konflik dan kekerasan. Hal ini disebabkan karena relasi antar sesama bukan didasarkan atas kasih tetapi relasi yang saling mendominasi. Ada banyak suami yang menganggap dirinya sebagai orang yang berkuasa atas istri dan anak-anak. Karena itu ia bebas melakukan apa saja termasuk mela- 
kukan tindakan kekerasan bagi anggota keluarganya. Faktor penyebab lainnya yakni budaya patriarkhi, di mana suami menganggap dirinya sebagai kepala bagi istri bukan sebagai mitra atau pasangan yang mengasihi dan menghormati keluarganya. Demikian juga dengan relasi antara orang tua dengan anak- dan tuan dan hamba.

Ada banyak para pekerja yang ditindas dan diperlakukan secara tidak adil. Para majikan sering kali mengabaikan hak-hak para pembantu dan memperlakukan mereka secara tidak manusiawi. Cara pandang dan sikap tersebut disebabkan karena pembantu tidak dilihat sebagai sesama atau anggota keluarga yang juga memiliki harkat dan martabat tapi sebagai orangorang yang memiliki kelas atau status sosial yang lebih rendah dari dirinya. Cara pandang tersebut menjadi salah satu alasan sehingga kadang para pembantu atau pekerja diperlakukan secara tidak adil dan diskriminatif. Demikian juga para pembantu harus Para pekerja (pembantu) harus memiliki komitmen dan bersungguh-sungguh dalam melakukan pelayanan, bukan karena keterpaksaaan, mencari untung dan nama, ingin menyenangkan hati tuannya, tetapi karena menghayati tugas dan pekerjaannya sebagai seorang pelayan bagi sesamanya.

Relasi antar keluarga sebagaimana yang diamanatkan dalam aturan haustafel ini menjadi dasar dalam orang membangun kehidupan keluarga yang damai dan harmonis. Keluarga adalah gambaran hidup jemaat (gereja) dan masyarakatnya. Apa yang diamanatkan dalam keluarga merupakan bagian dari kehidupan bergereja dan bermasyarakat. Dalam keluarga, setiap orang sungguh-sungguh mengalami dan merasakan kehadiran Tuhan yang mengasihi dan menerima umat-Nya apa adanya. Tuhan hadir dan memakai keluarga sebagai wahana untuk menyatakan kasih dan keadilannya bagi jemaat. Dalam keluarga orang belajar tentang cinta kasih, keadilan, kebenaran, keteladanan, penerimaan, pelayanan dan pengajaran Kristen yang benar. Dalam keluarga orang juga belajar tentang bagaimana menjunjung tinggi dan menghargai hak-hak orang lain, dan memperlakukan orang lain dengan adil dan setara. Semuanya itu berlandaskan pada Firman Tuhan. Keluarga harus menjadi rumah bersama bagi semua orang, sehingga melalui keluarga (anggota keluarga), orang mengalami Kristus yang hidup dan mengasihi gereja (jemaat-Nya).

\section{Kesimpulan}

Kode haustafel sangat menonjol dalam teks Efesus 6:1-9, di mana upaya memahami latar belakang pandangan nilai teologi haustafel tidak lepas dari latar sosial-kultural masyarakatnya, yakni stratifikasi sosial yang ditandai dengan adanya pola-pola relasi yang terbangun dalam masyarakat. Pola patron-klien yang sarat dengan praktik kekuasaan dan berdampak pada sikap dan perilaku sehari-hari, yakni saling mendominasi, praktik kekerasan dan ketidakadilan yang mengarah kepada perpecahan umat (gereja). Sehingga penekanan terhadap kesatuan tubuh dan nilai keluarga penting, sebagaimana tergambar dalam relasi anggota-anggota keluarga sebagai satu kesatuan tubuh, dan Tuhan sebagai kepala atas tubuh (jemaat). Dari hasil penafsiran, kandungan nilai-nilai haustafel yang ditekankan dalam perikop ini yakni nilai kebenaran, kasih dan ketaatan, penghormatan, nilai persaudaraan, bersikap adil dan setara, saling melayani dan menciptakan kehidupan yang damai dan harmonis. Nilai atau karakter mana terbentuk melalui proses pengajaran dan penerapan disiplin secara kontinue kepada umat. Sikap dan nilai teologi kekeluargaan menjadi gambaran atau model bagi gereja atau kekristenan dalam membangun relasi dengan sesama. 


\section{Referensi}

Hakh, Samuel Benyamin. Perjanjian Baru: Sejarah, Pengantar Dan Pokok-Pokok Teologisnya. Bandung: Bina Media Informasi, 2010.

Barclay, Willian. Pemahaman Alkitab Sehari-Hari, Surat Galatia Dan Efesus. Jakarta: BPK Gunung Mulia, 2015.

Cannon, George. The Use of Traditional Materials in Colossians. USA: Mercer University Press, 1983.

Green, Joel. "Slaves and Slavery in the Roman World", The World in the New Testament. Michigan: Grand Rapids, 2013.

. "Woman, Children and Families in the Grece-Roman World." In The World in the New Testament. Michigan: Grand Rapids, 2013.

Hukubun, Monike. "Nuhu-Met Sebagai Tubuh Kristus Kosmik: Perjumpaan Makna Kolose Dengan Budaya Sasi Melalui Hermeneutik Kosmik.” Universitas Kristen Duta Wacana, 2018.

Lenski, Gerhard. Power and Privilege: A Theory of Social Stratification. London: University of North California Press, 1984.

Louw, Johannes P, and Eugene Albert Nida. Greek-English Lexicon of the New Testament Based on Semantic Domains. Vol. 2 Indices. United Bible Soc., 1989.

Macdonald, Margareth. Colossians Ephesians. Sacra Pagina: Liturgical Press, 2008.

Newman, Barclay M. Kamus Yunani-Indonesia. BPK Gunung Mulia, 1996.

Osiek, Carolyn, and David L. Balch. Families in the New Testament World. Louisville: Westminster John Knox Press, 1997.

Schneiders, Sandra Marie. Women and the Word: The Gender of God in the New Testament and the Spirituality of Women. Vol. 1986. Paulist Press, 1986.

Tridarmanto, Yusak. Hermeneutika Perjanjian Baru 1. Yogyakarta: Kanisius, 2013.

Wijngaards, John. Yesus Sang Pembaharu. Yogyakarta: Kanisius, 1994. 